\title{
THE LIFE AND TIMES OF SIR RICHARD GREGORY, BT., F.R.S., I864-1952*
}

\author{
By SIR HAROLD HARTLEY, K.C.V.O., F.R.S.
}

$I^{\mathrm{T}}$ was at our meeting last year at Belfast that for the first time for more than fifty years we missed the presence of our most constant member, whose friendships and devotion to science, and his keen mind and sense of humour had given him a unique position as a vitalizing and constructive force in the work of the British Association. It is most fitting that this Pedler Lecture, which was his way of commemorating the work of Sir Alexander Pedler as secretary of the British Science Guild, should be a tribute to the life and work of our old friend Richard Gregory himself.

His life-history is a record of successful endeavour that would have delighted the heart of Samuel Smiles as an example of what courage and grit and devotion to science can accomplish. It is a thrilling story of heredity, circumstance, education and opportunity. Gregory was proud of his ancestry, and in his study hung a photograph of the inscription to his grandfather, a shoemaker of Bideford :

\section{"He was a consistent member of the Wesleyan Society for 65 years, And as a local preacher and Class Leader, His Labours were blessed \\ To the Salvation of Many Souls."}

John Gregory, his son, followed the same craft but also was one of Nature's poets. I found among Richard's papers this charming letter from $\mathrm{H}$. G. Wells to the old man when Richard had sent him one of his father's slender books of verse in 1907 .

\begin{abstract}
"Dear Mr. Gregory,
"You will I hope forgive my writing to you to tell you how much I like and value your book of poems. Your son has just given it to $m e$ and I have been reading in its contents a constantly increasing delight and surprise. He had often told me you wrote verse but he had given me no idea of the simple, curiously straightforward graciousness of your songs. They come $I$ think most appropriately with this spring time; they have so much in common with the bright freshness of primrose and aubrietia and all the daffodils and narcissuses with which the garden is singing. I have been reminded of Blake and Herrick and of all that is most truly English as I read. R.A.G. is one of my earliest friends-I didn't expect at this date to find a quite new reason for liking and respecting himin such a book as this.

"I am myself a sort of literary man though I've never risen to either verse or science. That must be my excuse for bothering you with these praises.

"Yours very sincerely,
\end{abstract} "H. G. WELLS."

Richard was born in 1864 in Bristol, where his father had moved from Bideford. When he was six he went to the Wesleyan Day School at Baptist Mills, where three hundred boys were taught in groups in one large schoolroom heated by a single fire-grate. In 1874 he entered the secondary school, now called Queen Elizæbeth's Hospital, a boarding school with a uniform rather like Christ's Hospital, where his

* Alexander Pedler lecture of the British Association, delivered in the Royal Institution, Iondon, W.1, on May 28. interest in science began. He left school early owing to his delicate health and began life like Faraday as a newspaper boy, and with his father more interested in poetry than shoe-making, it sometimes happened that his mother could buy no food until Richard returned with his weekly earnings. John Gregory must have had something in common with Blake and his idealism left its mark on Richard. One of his poems reveals his attitude towards wealth:

\section{"My heaven is not paved with gold ; For all that has been writ of it, I would not have it if I could, \\ There's blood on every bit of it. \\ I would not harm my angel's feet With such a hateful use of it; \\ I loathe, I scorn the thought unsweet, Because of man's abuse of it."}

When Richard was fifteen he was apprenticed to a boot factory for five years to learn the trade of clicking, that is, cutting out the various shapes of leather that were to be the uppers of boots and shoes. He was unhappy in his work and spent all his spare time attending evening classes in the Bristol Trade and Mining School (now the Merchant Venturers' College) and reading in the St. Agnes Club Library.

John Gregory was one of a band of socialist reformers in Bristol actively engaged in establishing the socialist and labour movement. The group included Ben Tillett, Jim O'Grady, later Sir James and High Commissioner in the Commonwealth of Australia. Ramsay MacDonald joined them for a short time in 1884 when he came to Bristol to help with a boys' club. At that time he meant to become a science teacher, and when he was Prime Minister he said to Richard, "You chose the better part".

Richard and his father were great friends and in those early years he was closely associated with him in his social work. At evening meetings John would give an address on some labour problem or recite some of his poems and Richard would sing or give a talk on a scientific subject, often astronomy, in which he was even then keenly interested. John Gregory became a well-known figure in Bristol and in 1912 he was given an honorary degree by the University, an honour which Richard was to share with him thirteen years later.

When he was seventeen he won the Latin prize at the Trade School. Canon Wilson, a great educational reformer, was then headmaster of Clifton; ho was an admirer of the personality and poems of Richard's father and often came to see him. He encouraged Richard with his Latin, and knowing his wish to leave the factory and learn science, he offered him the vacant post of laboratory assistant at the College. Richard had to secure his release from his indenture and paid an indemnity of $£ 5$, which A. M. Worthington, the physics master, lent him, to be deducted from his first term's wages. One of his congenial duties at the College was the care of the fine eight-inch telescope. 
Here at last came the opportunity he had dreamt of during his years at the boot factory and he took full advantage of it, continuing his studies in science and mathematics to such good effect that three years later he gained a scholarship in the Science and Art Department examinations which enabled him to become a science teacher in training at the Royal College of Science, South Kensington. Huxley was then dean of the College, and a new world opened for Gregory. He gained first classes in astronomy and physics and two years later, in 1887, he became a science demonstrator in H.M. Dockyard at Portsmouth. His main interest was still astronomy, and in 1889 he returned to the Royal College of Science as computor to the Solar Physics Committee and assistant to Norman Lockyer.

At each stage of his life Gregory was fortunate in his friends. At South Kensington he and H. G. Wells were fellow students and they were close companions. Wells has described in "Love and $\mathrm{Mr}$. Lewisham" and in his "Experiments in Autobiography" the aims and hopes and struggles of the students of the College at that time. Forty years later he wrote of Gregory: " $\mathrm{He}$ emerges in my memory as a bland and sturdy figure in the debating society, a little troubled then as ever about the letter ' $r$ ', friendly, hilarious, hard-up and working hard, one of the cheerful and often quite audible group which includes William Burton, the potter, and A. T. Simmons. We had no relatives to push us on, we had to do all our own pushing, and sometimes the pushing was very hard indeed.

"Gregory pushed his upward course by way of sunspot computation to the stars. $\mathrm{He}$ won the respect and confidence of Sir Norman Lockyer. But before his footing was well established there were some precarious times. I had not so much pushed my way up as out by starting the Science School Journal (which is now the Phoenix) and similar depravities and my times were even more precarious. We collaborated in a book on 'Physiography' (Gregory got the job for me) and earnt $£ 10$ each. 'Ten pounds were worth getting in those days. We lent each other money and returned it (though social observers declare that such returns never happen). We followed our destinies. All sorts of things happened to me but nothing ever changed the steadfast friendship and helpfulness of Gregory."

Gregory's work with Lockyer was of a routine nature, measuring the areas and positions of sunspots and faculæ in photographs taken during 1878-81 at Dehra Dun, Mauritius and Melbourne. H.e was also concerned in some unproductive work on the widened lines in sunspot spectra and he photographed the spectra of a number of elements. That was his only direct contact with research, and his name does not figure in any paper. But Lockyer's work on the orientation of temples in Greece and Egypt appealed to Gregory and was the start of his life-long interest in the relations of astronomy and religion.

Soon after ho joined Lockyer's staff, Gregory's articles and reviews began to appear in Nature: in 1889 "On the Determination of Masses in Astronomy" and "The Planet Uranus" ; in 1890 on "Comets of Short Period", "Lunar Photography" and "Electrical Storms on Pike's Peak". In the same year he became an Oxford University extension lecturer on astronomy and physies, and in 1892 he left the Royal College to become a free-lance lecturer and writer. Lockyer, however, had realized the quality and promise of his literary work and in 1893 made him assistant editor of Nature, which first brought him into touch with Macmillans, its publishers. So the opportunity came to Gregory to devote his life to securing recognition for science and scientists, and to ensuring that they were given the chance to make the contribution to progress on which he believed the future depended. He had come up the hard way and he did his best to awaken a realization of the readjustments in social and economic conditions that the new technical age was making imperative. Gregory used every means of reaching his objective : education, journalism, the British Association and the British Science Guild.

\section{Education}

Cregory had had to fight so hard for his own education and had suffered so much from the lack of text-books that he saw here a great opportunity. His first book, "Flementary Physics and Astronomical Geography", was published in 1891. It was the first of many text-books that flowed from his ready pen or were inspired by his editorship. His own books were notable for their clear writing, systematic arrangement, for their rocognition of the relation of theory and practical work, and for the lively interest they created in the practical applications of science. His second book was an elementary physiography, a description of the laws and wonders of Nature. After that came "Honours Physiography" with H. G. Wells in 1893, and in the same year "The Vault of Heaven", and next year "The Planet Earth". Meanwhile, he was getting experience as an Oxford University extension lecturer and in 1898 he became professor of astronomy at Queen's College. The same year saw the beginning of his long partnership with A. 'T. Simmons, with whom he started the School World (later incorporated in the Journal of Education) and the series of joint text-books, which they produced in new editions until Simmons's death in 1921.

In 1905 Gregory became scientific editor to Macmillans, a position he held until 1939. Under his editorship and inspiration some two hundred textbooks were published, many with him as co-author.

In the years when science was becoming an increasingly important subject in the schools, this comprehensive series of text-books covering elementary and advanced courses was a contribution of great value. Gregory devoted himself to this work, and many authors, young and old, were grateful for his encouragement and his wise advice and criticism. Editorship for him meant a working partnership with the author at every stage of a book.

But his interest in education did not end with writing and editing books. He was keenly interested in the technique of teaching, in the many problems to be found in the introduction of what was often a new subject and in securing the proper place for science in the curriculum. It was these wide interests that led him to take such an active part in the formation of Section I (Education) of the Pritish Association in 1901. He was its first sccretary and then its recorder, and one of its most active members from the start. 'The turn of the century had seen a big extension of school science and many experiments were boing tried.

Gregory, in his presidential address to Section $\mathrm{L}$, when it came of age in 1922, gave a sketch of its aims and progress. It had been formed to devote attention to education in all its branches with the object of introducing scientific conceptions into every sphere of educational activity. Gregory defined the business of education as the promotion of the right 
adjustment of a growing human being to its environment. The scope and character of the subjects of instruction should be determined by this biological principle and must be adjusted to new conditions in the world. "Science has become a kingdom potent with possibilities for good or evil-an inheritance which cannot be renounced-and to let any children grow up unfamiliar with their entailed possession is to neglect an obvious duty. . . . Science permeates the atmosphere in which we live, and those who cannot breathe it are not in biological adjustment with their environment-are not adapted to survive in the modern struggle for existence."

Gregory knew the kind of science teaching he wanted to see in schools; its purpose was not "to prepare for vocations but to equip pupils for life as it is and as it soon may be".

He was chairman of a British Association Committee in 1917 which was appointed to report on the essential place of science in school education. It included among its members several outstanding teachers like Sanderson of Oundle and Archer Vassall, and the report with its suggestions for science courses was the foundation of the movement towards general science. Gregory insisted that general science should be more than an amorphous collection of topios from physics and chemistry with a little natural history thrown in as a sop to the biologists. "It should provide for good reading as well as for educational observation and experiment; should be humanistic as well as scientific. The subject which above all others has the double aspect is geography. . . Rightly conceived, geography can be made the earliest means of education as both Comenius and Locke regarded it, and it can be used as the unifying principle of all the generalized scientific instruction in schools." To-day with our greater knowledge of the world's resources and demands, of the needs of backward countries, of the principles of nutrition and disease, Gregory's forecast is seen in a new light.

He was very critical of examination syllabuses of the type of university entrance examinations which meant sacrificing the needs of the many to the interests of the few. While recognizing the value of laboratory work as a training in method, he was insistent on its being accompanied by broad courses which would excite wonder and stimulate the imagination, while providing a knowledge of everyday phenomena and the applications of science. His address was a plea "for the expansion of scientific instruction in this humanizing spirit, and for widening the gateway into the land of promise where the destinies of the human race are shaped. . . . I want science not only to be a means of stimulating real and careful thinking through doing things, but also a means of creating interest and enlarging the working vocabulary of the pupils and thus truly increasing their range of intelligence. So may scientific instruction be made a power and an inspiration by giving, in the words of the Book of Wisdom (vii, 16-20) :

"An unerring knowledge of the things that are,

To know the constitution of the world and the operation of the elements :

The beginning and end and middle of time,

The alternations of the solstices and the changes of seasons ;

The circuits of years and the position of stars ;

The nature of living creatures and the raging of wild beasts,

The violences of winds and the thoughts of men,

The diversities of plants and the virtues of roots."
The late Poet Laureate shared Gregory's views. He spoke at the great meeting that was held in May 1916 to direct attention to "The Neglect of Soience" which was prejudicing in many ways our war effort. It is probably scarcely even a memory to many; but the recollection of it is a reminder of the progress we have made since then, thanks in no small degree to Gregory's persistent advocacy. Robert Bridges in his final sentence crystallized the inward significance of this new view of scientific learning in the schools. "It is," he said, "the living grammar of the universe, without which no man ean ever hope to read in its full significance the epic of his spiritual experience."

For his presidential address to the Science Masters' Association in 1928, Gregory chose as his subject "Contacts of Science and Literature". "As my main functions in life," he said, "seem to be those of a scribe and guide, it is perhaps appropriate that in this address I should deal with language and literature in relation to science rather than with scientific education or progress." Gregory was an omnivorous reader all his life and he had a good literary memory. He begins by comparing the outlook of the scientist and the poet, the one desiring to see things as they are, the other to display the emotional feelings aroused by them. But as Gregory shows by quotations from Tennyson and Shelley, their intentions are not necessarily opposed. Scientific truth may often be turned to poetic purpose. He quotes the verse from "The Cloud":

"I am the daughter of earth and water,

And the nursling of the sky ;

I pass through the pores of the oceans ard shores;

I change, but I cannot die."

Those lines had often been set for comment in elementary science examinations, and Gregory wonders whether students of English could interpret them so successfully. That leads him on to question whether the indifference to science among the teachers of English is not more general than the neglect of literature by students of science. Gregory was always pressing for a balanced education, and he resented the intransigent attitude of scholars and writers educated in classical schools towards the claims of science to an essential place among the new humanities. $\mathrm{He}$ rejects on the evidence of the psychologists the concept that the exercise of the mind on one kind of material improves the faculty to deal with all kinds of material, part of the basis of the claim that training in the classics is of unique volue. But Gregory was a Hellenist with a deep appreciation of "the passionate regard for truth, disinterested research, imagination, acute reason and creative intelligence, which were the essence of the Greek spirit". He admits that "to certain minds a grammatical generalization is more readily understood than a principle derived from laboratory measurements, and on that account some pupils who have been trained to apply scientific method to language may be better prepared to take up the study of science seriously than those in whose minds are nothing but loose ends". What judgment could be fairer? And he ends with an appeal to teachers of English, classics and history to understand and interpret the human contacts of science with their own subjects, resulting in "a unity of interest which will give power and a new meaning to all cultural effort".

His book "Discovery" was one of Gregory's many services to education. Published in 1906 , it ran 
through many editions until in 1949 Gregory revised and shortened it for the Penguin Press, so that the younger generation will not read it in its original form. This I regret, as it had a quality of its own in giving a picture of the working of the minds of the great discoverers. Instead of following the historical sequence, Gregory's chapters deal with the different aspects of discovery : outlook and endeavour, the scientific mind, belief and evidence, law and principle, scientific motive and practical purpose. The book is a revelation of his wide reading, of his first-hand knowledge of the classics of science and of his amazing literary memory. It is interspersed with long quotations from the classic authors which are so aptly chosen that they fall imperceptibly into line with his own lucid lively sentences, while revealing the thoughts of many of the greatest scientists of the past and the literary quality in which they found expression. The quotations at the head of each chapter show, too, Gregory's range and discernment. The book has such freshness and vitality, it arouses human interest on every page, it is written with such zest and enthusiasm that it should be reprinted in its original form.

Sir Edward Salisbury, a few weeks ago, when he was opening the new biological laboratory of the University College of the South West of England, spoke of the present-day danger of specialization of the young scientist confined within the ever-growing complexity of his own field. Gregory's appeal was for some knowledge of the purpose and accomplishment of science by the young layman. His book "Discovery" seems to me so admirably suited to meet this dual need as an introduction which will arouse interest and stimulate wider reading. Gregory carried in his mind the whole story of discovery through the ages, he knew the personalities of the great men and their writings, and so with the touch of the journalist at his best, carrying his learning lightly, he has given us this vivid picture of the different aspects of the advance of knowledge. Astronomy, geology, biology, chemistry and physies are all woven together, as he drew his examples from the old masters and the new.

\section{Journalism}

Almost from the day that Gregory became Lockyer's assistant in $\mathbf{1 8 8 9}$ he was writing popular articles on astronomy, and Lockyer was quick to see the qualities-his lucid style, his gift of phrase, his sense of the significant-that were to make Gregory the greatest scientific journalist and editor of his time. Love of science and an imaginative sense of the part it was destined to play in human affairs were the mainsprings of Gregory's life. But in addition he had the shrewdness and the practical judgment, sharpened by his early struggles and adversity, which helped so much in the success of his editorship of Nature. Of all his presidential addresses-and he must easily hold the record both for their number and the variety of their subjects-his address on "Science and the Press" to the Association of Special Libraries and Information Bureaux (now Aslib) at Oxford in 1934 is in some ways the most significant as it contains a searching analysis of the parts an editor and a manager must play in the life of a newspaper. It reveals how his keen mind had appreciated the factors that make for success or failure. It is interesting to compare it with the terse crisp sentences in which C. P. Scott wrote "On Journalism" in the centenary number of the Manchester Guardian. 'The two men thought alike. "In all living things," wrote
Scott, "there must be a certain unity, a principle of vitality and growth. It is so with a newspaper, and the more complete and clear this unity, the more vigorous and fruitful the growth. . . A newspaper has two sides to it. It is a business, like any other, and has to pay in order to live. But it is much more than a business; it is an institution; it reflects and influences the life of a whole community; it may affect even wider destinies. It is, in its way, an instrument of government. It plays on the minds and consciences of men." Nature under Gregory certainly became an institution, both in the international and in the national fields, for he made it a clearing-house for new ideas. A letter to Nature became the accepted channel of rapid communication to the scientific world of a preliminary note of some new technique or discovery. But that was only one of its functions.

Lockyer made Gregory his assistant editor twentyfour years after he had founded Nature. As years went by, more and more of the work fell to Gregory and he was virtually editor a long time before Lockyer resigned the office to him in 1919. Gregory had his own ideas, and new features were introduced, like the leading articles, the first of which appeared in October 1915 on "Science in National Affairs". From November 1919 when he took over, they appeared every week, many from his own pen, dealing with scientific developments which had national importance. Some of their titles in 1919-20 indicate Gregory's wise discrimination and foresight in the subjects he chose: the nurture of key industries, the need for aircraft research, the organization of scientific work in India, meteorology and the State, science and the new Army, the cost of scientific publications, the present state of the dye industry, naval education, aerial navigation and meteorology.

T'he years of Crregory's editorship saw an immense increase in the number of scientific workers and a rapid growth of specialization with the increasing complexity of problems in each field. Entirely new fields of investigation were opened with new techniques, and there was a great extension of industrial research. All this combined to make it more difficult to watch developments all over the world. But under Gregory's skilful guidance Nature made this possible.

The late Lord Rayleigh, in thanking him for his Hinchley Lecture to the Institution of Chemical Fngineers, on "Scientific Knowledge and Action", spoke of the great debt that all scientific men owed to Gregory for more than a generation. Looking back on his own scientific life, he said that he found it difficult to imagine how he could have carried on if he had not had the constant privilege of reading the pages of Nature, a journal which kept one in touch with science in all its branches. I remember very well as a schoolboy being introduced to Nature by H. B. Baker-.."dry reaction Baker"-and I read it eagerly each week. When I returned from a scholarship examination at Oxford, Baker greeted me by saying, "Well, your reading of Nature must have paid a good dividend", and from my point of view it certainly had.

Lord Rayleigh spoke of the nice discrimination with which Nature avoided any reference to discoveries like the death ray which were trumpeted in the daily press, and his own reliance on the authority of Nature. He wondered how Gregory managed to keep in touch with all branches of science in all countries; "but somehow or other the thing was 
done and scientists as a whole were glad to benefit by the result, even if they were mystified by the process".

In his early years Gregory stood almost alone as a scientific journalist, and in his Aslib address he lamented the scant encouragement given to science writers, since so few newspapers or periodicals had on their staff someone capable of dealing intelligently with scientific subjects, of equal standing with their special critics of art and music, or of racing, golf and tennis. As a result the public lack in science the enlightened guidance they receive in other matters. "Most people have yet to learn," he said, "how and why science and scientific thought are the determining factors in the chief problems of progressive life."

Gregory admitted that one difficulty was that many investigators were too busy and were often ill-fitted to be popular interpreters, which made it all the more important that there should be a class of science writers with some organization behind them, like Science Service, the non-profit-making corporation in the United States, founded in 1921 by a newspaper editor and proprietor, the late Mr. E. W. Scripps. He ended with an appeal to the press and to the men of science to get together and find a remedy.

That address was given nearly twenty years ago, and Gregory's advice has not gone unheeded. Particularly in the B.B.C. much has been done to make the public realize the outlook of the scientist and the impact of his work in almost every field of social and political well-being. Gregory took an active interest in establishing the Association of British Science Writers, of which he was the founder president.

It needed the experience of a Second World War to drive home the lessons of the First, but that demonstration of the power of science left in the minds of many a deep mistrust. Gregory himself repudiated the use of the atom bomb as repugnant to the ethics of the civilized world.

British Association and British Science Guild

Of the many attachments Gregory formed during his life the longest and the most intimate was his membership of the British Association, and it was there that he was best known to the younger generation. He joined as a life member in 1896 and his attendance came near to being proverbial. In his telegram last year to us at Belfast he spoke of urbroken attendance at fifty-two meetings. From the first he threw himself into the work of the Association with immense energy and devotion, not only in Section L, but also on endless committees and as a member of Council for many years. He was always ready with constructive suggestions and he was one of the stalwarts who gave continuity to our meetings. The B.A. owed much to Gregory, but the debt was amply repaid when at the meeting in South Africa in 1929 he met in Johannesburg his future wife. She, too, has won our affection by her devoted care of her husband, who relied more and more upon her as years went by. Let me quote (Yregory's own tribute to her: "My dear wife Dorothy has brought into my life more happiness than anyone else and whatsoever I may possess when I am called away cannot be more than a poor return for her sweet love and tender care".

But much as Gregory believed in the British Association, he followed Lockyer in thinking that its activities should be extended to influence public opinion and promote closer contact between seience and public affairs.
In his presidential address at Southport in 1903 on "The Influence of Brain-Power on History", in which he paraphrased the title of Captain Mahan's famous book which did so much to arouse public interest in the Royal Navy, Lockyer urged the need for an organization to enable science to speak with a collective voice, so that it might counter the neglect. which had become so dangerous, when Britain's industrial and military strength were both threatened with severe competition from abroad, competition based on education and scientific research. Lockyer gave striking figures to show how science was being starved in Britain as compared with the large sums being spent in Germany and the United States on the endowment of universities and research. He quoted Huxley's dictum that we were in the presence of a new "struggle for existence", a struggle in which science and brains take the place of swords and sinews, the result of which would be decided in the school, the university, the laboratory and the workshop.

It is perhaps difficult for the present generation to realize how backward we were. The total annual Government grant to universities and university colleges in Great Britain in 1905 was $£ 155,000$, while the University of Berlin ten years earlier was receiving $£ 167,000$. Lockyer pleaded for a duplicate of the Navy Bill of 1888 when $£ 21 \frac{1}{2}$ million were voted for a five-year building programme.

Quoting the last words of the original objects of the British Association-" "to obtain a more general attention to the objects of science and a removal of any disadvantages of a public kind which might impede its progress"--Lockyer argued that here was a great opportunity to expand its functions. "This magnificent, strong and complicated organization would become a living force, working throughout the year instead of practically lying idle, useless and rusting for fifty-one weeks out of the fifty-two so far as its close association with its members is concerned.'

However, the Couneil did not see its way to set up such a wide organization as Lockyer had outlined, possibly doubting the wisdom of becoming involved in national and political affairs. So the British Science Guild was formed in 1905, with Lord Haldane as its first president, with the objects of creating a general awareness of our future dependence on scientific method and research, of pressing for greater support for universities and research institutions, and of bringing to the notice of Parliament the scientific aspects of matters affecting the national welfare.

Gregory was at first a little doubtful about this breakaway from the Association; but he soon saw the advantages of the Guild as an agenoy fir propaganda, backed by men in public life like Lord Haldane, Lord Sydenham, Lord Montagu of Beaulieu and Lord Melchett. By public meetings, by reports of committees, by lectures and by close contact with members of Parliament, it was able to stimulate public interest continuously during the critical years of scientific development. Some twenty urgent national problems concerned with scientific effort were investigated by strong committees, and in this way the Guild made a major contribution towards a number of improvements, among them : the 'Treasury grant for developing a National Physical Laboratory ; the creation of the Development Commission for Agriculture ; the establishment of a Depariment of Scientific and Industrial Research; the Patent Act of 1932 ; and the formation of the Parliamentary Science Committee. 
In all of this Gregory soon became the moving spirit, and from 1922 he was chairman of the Executive Committee. He drafted many of the reports, and the work of the Guild had strong support in Nature. He organized the exhibitions of British Scientifie Products in 1918 and 1919, for which he received the recognition of a knighthood.

There is no doubt that the Guild did most valuable work, and the Norman Lockyer and Alexander Pedler Lectures founded in 1925 and 1929 were a constant reminder of the importance of science in human progress. In 1923, when the first suggestion was made to unite the Guild and the Association, Gregory was opposed to it, as in his view the two bodies were essentially different. "The B.A. consists of priests and noviciates of science, while the B.S.G. represents a missionary effort to proclaim a new gospel." Negotiations were renewed from time to time, and finally in 1936 proposals for amalgamation were approved by the British Association at the Blackpool meeting. In 1938 the Division for Social and International Relations of Science was formed with a committee embodying the existing British Science Guild Committee, with powers to hold meetings not necessarily confined to the annual meetings of the Association, and a new journal, The Advancement of Science, was substituted for the old annual report.

It is true that the Division under Gregory's presidency kept the Association active during the War. But looking back at what the Guild accomplished and looking forward to the problems Great Britain has to face, I question whether the fusion was in the best interests of science. Has not Gregory's original objection been fully justified by the results ? The Guild could enlist the sympathy and leadership in the cause of science of men in public life. It provided a forum where a group of men of affairs could discuss with men of science. Under Lockyer's and later Gregory's watchful eye it could and did address itself immediately to national problems when science was concerned. Its success in later years was due largely to the energy and vision of Gregory and his friends. It was not only a missionary but also an invaluable watchdog. Has its offspring, the Parliamentary and Scientific Committee, effectively taken its place?

\section{The Visit to America}

In December 1938, just as he was leaving the editorial chair of Nature, Gregory was invited to givo a series of lectures in the United States at the Carnegie Institution, Columbia, Harvard and Johns Hopkins Universities, and to address our sister body, the American Association for the Advancoment of Science.

The tour was a great success, for Gregory was at his peak in his seventy-fifth year as an eloquent exponent of the gospel of science, and he felt the thrill of the occasion. $\mathrm{H}_{\Theta}$ had seen clouds gathering on the horizon and his addresses were a declaration of his faith in what science could contribute to a disordered world if it were not perverted to destructive uses in the lust for power. Gregory feared the growing tide of nationalism as a disintegrating force in a world which science could help to unify. In 1938 he recalled Soddy's Cassandra-like prophecy of the atom bomb.

The Greeks had dreams of the Golden Ages of the past, they had no word for progress ; but Gregory had visions of the Golden Ages of the future, if man would use his new understanding of Nature to good purpose.

His Elihu Root Lecture to the Carnegie Institution of Washington, on "Cultural Contacts of Science", was the most finished and carefully argued of all his addresses, and it gave the best picture of the run of his mind and interests. It deserves to be reprinted, as it is unknown in his own country. In it he counters the view that scientists are materialists, insensitive to beauty and incapable of deep emotion, that the scientist's idea of the evolution of mankind is the law of the jungle, "Nature, red in tooth and claw". Through all his American addresses there runs the motive of his favourite quotation from Huxley, his dean at South Kensington, in "Evolution and Ethics": "In place of ruthless self-assertion it demands self-restraint in place of thrusting aside, or treading down or competition, it requires that the individual shall not merely respect but shall help his fellows; its influence is directed not so much to the survival of the fittest, as to the fitting of as many as possible to survive".

The future of the world depends, Gregory said, on the use of science in the spirit of the Sermon on the Mount.

One of the themes of the Elihu Root Lecture was the relation of science and literature. He quotes fine passages from Kepler and Newton, examples of de Quincy's "literature of power" as contrasted with "literature of knowledge", which "survive because of their human feeling naturally expressed". He quotes the famous passage in Wordsworth's introduction to Lyrical Ballads: "Poetry is the wealth and fine spirit of all knowledge ... it is the impassioned expression which is in the countenance of all science". "Poctry," says Gregory, "and other forms of literary and artistic expression once followed more closely on knowledge than they do to-day. ... Poetry, philosophy and science all began life together as children of one family. . . The greatest singers of antiquity were the most alive to science." Then he turns to the history of the earliest science, astronomy-" "The science most closely associated with spiritual feeling", and traces its relationships through the ages to religion and other reflexions of current thought in literature and philosophy. He follows the gradual emergence of the conception of law and order to Nature and of divine purpose through the study of celestial bodies in Babylon, in Egypt and in Greece. Then from his knowledge and love of literature he illustrates the inspiration that came from man's contemplation of the skies in the Bible and in the poems of Virgil and Lucretius, of Dante, Chaucer and Milton.

Through all this Gregory is tracing the pursuit of truth and its high moral and spiritual influence in whatever field it is the motive of action. Science is not to be regarded, "merely as a store house of facts to be used for material purposes, but as ono of the great human endeavours to be ranked with arts and roligion as the guide and expression of man's fcarless quest for truth".

When he returned from America, Gregory collected all the materials for his lectures and embodied them in a book, "Religion in Science and Civilization". 'This was published in 1940 , but alas nearly all the copies were destroyed in an air-raid, and then with his energy unabated at the age of eighty, he set to work and recast it under the title of "Gods and Men", which was published in 1949. Among the many appreciative letters he received about the book, 
those from Dr. George Trevelyan and Mr. Mackenzie King gave him special pleasure. Dr. Trevelyan said he was astonished that one who had given his life to science should have been able to take so wide and deep an interest in history. "I see you are a great age now which makes my wonder of the book all the more." Mr. Mackenzie King, writing just after his resignation of the premiership of Canada, said that the book had given him what he most needed-" A place of new beginning; something to restore a true perspective".

\section{Presidency of the British Association}

In 1939 came the Second World War and Gregory had been elected president at Dundee the day before war broke out. The annual meetings of the Association had to be abandoned, but the formation of the Division for the Social and International Relations of Science gave the opportunity under Gregory's leadership for a series of conferences to discuss questions that would be in urgent need of solution when the War ended. The ideas of the founders of the British Science Guild were thus given scope for expression and action. There were eight conferences in all over which Gregory presided, and at the first, on "Science and World Order", he enunciated a "Declaration of Scientific Principles" which was in effect a Hippocratic Oath for scientists.

These conferences kept the Association in action during the War and they certainly achieved their object in providing opportunities for the discussion of post-war problems. Their subjects covered a wide field and perhaps the most successful were those on mineral resources, the place of science in industry, and science and the citizen, at which Gregory read a paper on "Science and the Press", in which he emphasized the need for continued education on the impact of science on social relations.

Gregory's was the record presidency of seven years, from 1939 until 1946, when he delivered his presidential address at the first short post-war meeting in July. His subject was "Civilization and the Pursuit of Knowledge". In it he recurs to the favourite topic of his later years, the gradual emergence of civilization through the ages and the history of early religion with its elose association with the heavens. Then he outlines the development of the schools of philosophy and the growth of natural knowledge, science and invention. Gregory's anxiety was the use that man might make of his new powers, and he ends with a moving appeal for goodwill and goodness of heart in the choice between the good and evil fruits of knowledge.

His last speech to the Association was at Birmingham, when he moved the vote of thanks to Bishop Barnes for his Sunday evening discourse on "Science, Religion and Moral Judgments". The Bishop's subject was close to Gregory's heart and he was at his happiest in his appreciation of the address, with all his old zest and enthusiasm and his readiness to find le mot juste. We saw him for a brief space at Edinburgh, where he was taken ill; for a year he was an invalid and then in September 1952 his active spirit quietly flickered out.

\section{Epilogue}

I began with the idea of making this lecture mainly a study of the times of Richard Gregory, but I quickly found those times becoming just a background to the human interest of his life of endeavour and success-a success which is so encouraging a story in the days when there were few of the educa- tional escalators of the present time. I have told the story so far as possible in his own words, which were so well chosen.

Gregory's long life of nearly ninety years saw the most rapid and eventful changes in the outlook and fortunes of mankind. First came the battle between the evolutionists and creationists and the emergence of the liberal interpretation of the Holy Scriptures that we know to-day. Next came the gradual recognition of our social responsibility for the human adjustments that are needed in an industrial civilization, which has changed so profoundly the social structure of Britain. Alongside them came that pride of discoveries, the electron, the nucleus, the quantum and relativity, that have given a fresh insight into the nature of matter, of life and of the universe. With that deeper insight has come a new humility in response to the ever-receding vistas of the complexity of the unknown.

With the advance of knowledge came a new power of man over his environment, the possibility of a new partnership with Nature in place of the struggles of primitive man. Evolution has moved fast, quickened by the needs of two world wars, that have left such deep scars behind them.

Of all this Gregory, so far as science was concerned, was the interpreter, or as he called himself once "the standard bearer', and he had ideal qualities for the task. He was no specialist, nor in that sense a profound thinker; he did not engage in the details of polemies. He saw the broad picture and its human bearings, for he was essentially a humanist. He had the gift of leadership-persuasive, resourceful and quick in action. He had a ready humour and a fund of stories. But above all he was one of the most generous of men, generous in his help and gifts, generous in his praise, and sometimes too generous of other people's motives.

Success and recognition eame to him in many ways and he enjoyed them to the full. It was his generosity towards others that made his successes such a pleasure for his friends. The honours that pleased him most were his knighthood and his baronetcy, his election to the Royal Society under Statute 12 in recognition of his conspicuous service to the cause of science, his election to the Athenæum under Rule II, his honorary membership of the old Cliftonian Society, the presentation to Lady Gregory and himself from the British Science Guild, and finally his presidency of the British Association.

Gregory was an optimist: he saw the best in everything and everybody. This made him sympathetic to new movements, ' which seldom came to him in vain for help. Perhaps, too, it was partly the inveterate old journalist in him peeping out, eager for news. From first to last he was a member of more than seventy societies and institutions and a moving spirit in so many. But it is as the editor of Nature that he will be best remembered in the future, for his wise, shrewd, imaginative guidance that gave Nature its unique position in the scientific literature of the world. The driving force behind all he did was his devotion to the interests of science and his belief in its message for the future. Gregory wrote his own epitaph :

"My grandfather preached the Gospel of Christ ;

My father preached the Gospel of Socialism ;

And I preach the Gospel of Science,

But the ethical principles of all three are pursuit of truth and righteousness for the improvement of man and society." 